Annals of Plant Sciences

ISSN: 2287-688X

OPEN ACCESS

www.annalsofplantsciences.com

Research Article

\title{
Studies on mycorrhizal biodiversity in medicinal plant species of Pookode Lake area, Wayanad, India.
}

Saranya Babu Jayaprakash C.M.* and N. Nagarajan

PG and Research Department of Botany, Kongunadu Arts and Science College (Autonomous), Coimbatore - 641

029, Tamilnadu, India.

Received: 2017-10-17; Accepted: 2017-10-24

\begin{abstract}
Forty different medicinal plant species were investigated for arbuscular mycorrhizal association from Pookode Lake area, Wayanad district, Kerala. The spore density and percentage of infection varied with plant species. The percentage of AM fungal colonization ranged from 30 to 80. The highest AM fungal infection was exhibited in Centella asiatica (80\%) and maximum spore population in Lencas aspera $(690 / 100 \mathrm{~g})$. Totally 36 arbuscular mycorrhizal fungal species were recovered from the rhizosphere of 40 medicinal plant species belongs to 20 plant families. The arbuscular mycorrhizal spore species Glomus fasciculatum was found dominant.
\end{abstract}

Keywords: Glomus, medicinal plants, mycorrhiza, wayanad

\section{Introduction}

The plant in natural habitat forms association with large number of microorganisms; one among them is AM fungi. AM fungi are an important component in the soil microbial mass which regulates several essential biological processes at the plant soil interface. The majority of higher green plants and large number of AM fungi are involved in mycorrhiza formation (Harley, 1989). They regulate the abundance of plant community (Allen et al., 1995). The symbiotic association between fungi and the roots of higher plants comes under the general name 'Mycorrhiza' which literally means fungusroots. The mycorrhizal fungi as one of the important biological component of soil have been reported to play important role in the regeneration of the abandoned forests because of their symbiotic association with the plant roots.

Mycorrhizal fungi occur in nearly all soils throughout the world and form symbiotic associations, the fungal symbionts inhabiting the root forming a second absorptive organ for the host. As the most widespread symbiosis on earth (Brachmann and Parniske, 2006), AM fungi evolved concurrently with the first colonization of land by plants some 450 to 500 million years ago and persist in most extant plant taxa (Cairney, 2000). The AM associations can increase plant growth, in many cases by enhancing phosphorus uptake from soils with low to moderate phosphorus availability (Powell, 1984). AM fungi are major components of rhizosphere microflora in natural ecosystems and play significant role in the reestablishment of nutrient cycling (Peterson et al., 1985). Due to their unique position at the root-soil interface, AMF have been described as "Keystone Mutualists" in

*Corresponding Author:

Mr. Saranya Babu Jayaprakash C.M., PG and Research Department of Botany, Kongunadu Arts and Science College (Autonomous), Coimbatore - 641 029, Tamilnadu, India.

E-mail: saranyaharmesh08@gmail.com ecosystems (O’Neill et al., 1991). The great interest in $\mathrm{AM}$ in recent years has prompted numerous survey aimed at enumerating and assessing AM fungi in a particular region or in a natural environment. A study has been done to find the arbuscular mycorrhizal fungal spores in the rhizosphere soil samples of medicinal plant species and the rate of mycorrhizal infection in their roots.

\section{Materials and Methods}

\section{Study area- Pookode Lake}

The Pookode Lake is a natural water body of about 7.5 ha surrounded by a chain of hills rising to the order of $800 \mathrm{~m}$ above mean sea level. This lake is located in Kunnathidavaka village between $11^{\circ} 34^{\prime} \mathrm{O}^{\prime \prime}$ and $11^{\circ} 32^{\prime} 24^{\prime \prime} \mathrm{N}$ latitude and between $76^{\circ} 1^{\prime} 24^{\prime \prime}$ and $76^{\circ} 14^{\prime \prime}$ E longitude in the Vythiri taluk of the Wayanad district, $16 \mathrm{~km}$ towards the west of Kalpetta- the district headquarters.

\section{Soil sample collection:}

Totally 40 medicinal plant species belonging to 20 families namely Apiaceae, Asteraceae, Acanthaceae, Apocynaceae, Chloranthaceae, Cyperaceae, Lilliaceae, Lamiaceae, Malvaceae, Melastomataceae, Mimosaceae, Onagraceae, Poaceae, Polygonaceae, Rubiaceae, Solanaceae, Scrophulariaceae, Tiliaceae, Urticaceae and Verbenaceae were collected from Pookode Lake in the period November 2009 to January 2010. Root samples and rhizosphere soil samples of medicinal plant species growing in and around the areas of Pookode Lake were collected. The root and soil samples were transported to the laboratory immediately after collection. 
The plant species selected for the study are Sida rhombifolia L, Urena lobata L, Triumfetta rhomboidea Jacq, Mimosa pudica L, Osbeckia octandra DC, Ludwigia octovalvis (Jacq.) Raven, Centella asiatica (Linn) Urban, Hydrocotyle javanica Thunb, Ophiorrbiza mungos Linn, Spermacoce ocymoides Burm.f, Ageratum conyzoides Linn, Blumea membranacea (DC.) Hook.f, Dichrocephala integrifolia (L.f) O. Kuntz, Elephantopus scaber L, Erechtites valerianifolia (Wolf) DC, Spilanthes ciliata H.B.K, Spilanthes radicans Jacq, Vernonia cinerea (L.) Less, Wedelia trilobata (L.) A.S. Hitchc, Rawvolfia serpentina (L.) Benth.ex Kurz, Rawvolfia verticillata (Lour) Baill, Solanum nigrum L, Solanum surattense Burm.f, Solanum torvum Sw, Lindernia antipoda (L.)Alston, Mecardonia procumbens (Mill.) Small, Scoparia dulcis Linn, Andrographis macrobotrys Nees, Strobilanthes beyneanus Nees, Lantana camara L, Stachytarpheta jamaicensis (L.) Vahl, Leucas aspera (Willd.) Spreng, Pogostemon paniculatus (Willd.) Benth, Polygonum chinense Linn, Sarcandra chloranthoides Gard, Elatostema lineolatum Wight, Asparagus racemosus Willd, Kyllinga monocephala Rottb, Paspalum conjugatum Berg and Panicum brevifolium L.

\section{Estimation of Arbuscular Mycorrhizal colonization in roots \\ Root samples:}

Root samples, 5-15 cm long, were collected from the medicinal plant species during November 2009 - Jan 2010. During collection, care was taken to ascertain individual plants for which roots could be positively identified as belonging to a particular plant species. For identification and nomenclature of plant species the following manual was used (Mathew, 1983).

\section{Soil samples:}

The rhizosphere soil, dug up to a depth of $10 \mathrm{~cm}$, was collected from each plant species after removing the surface soil and litter covering. These samples were kept in sterilized bags and were transported to the laboratory immediately after collection for the examination of vesicular arbuscular mycorrhizal fungal spores association.

\section{Sample preservation:}

In the laboratory, the roots were separated from soil, by wet sieving. The roots were washed with water and processed afresh whenever possible. Otherwise the washed roots were fixed in formaldehyde-acetic acid-ethanol (FAA) solution (90:5:5 V/N) [modified method of Phillips and Hayman (1970) as mentioned in Cade-Menunet al. (1991). The soil sample was air dried and stored at $4^{\circ} \mathrm{C}$ until processed. Each soil sample was used for chemical analysis, spore counts and classification into various types and multiplication, concentration and separation of AM fungal spore for identification.

\section{Preparation of soil samples for analysis:}

Each soil sample was spread on a flat wooden or plastic tray and was allowed to dry in air under shade. Stones and pieces of macro organic matter were removed. Large lumps were broken by hand and the soil was ground by rolling gently with a wooden roller. After grinding, the soil was screened through a $2 \mathrm{~mm}$ sieve and the fine soil was used for further analysis.

\section{Evaluation of AM infection}

The root samples were cleared and stained in tryphan blue with a modified version of the Philips and Hayman's (1970) method. Roots were cut into 1-2 $\mathrm{cm}$ pieces, heated at $90^{\circ} \mathrm{C}$ in $10 \% \mathrm{KOH}$ for about 1 hour. For thicker and older roots, the duration was increased. The root segments were rinsed in water and acidified with dilute HCL. The root pieces were stained with $0.05 \%$ tryphan blue in lacto phenol for 5 minutes and the excess stain was removed with clear lacto phenol.

The pigmented roots were heated at $90^{\circ} \mathrm{C}$ in $10 \%$ $\mathrm{KOH}$ for 2 hours, washed with fresh $10 \% \mathrm{KOH}$ and immersed in an alkaline solution of $\mathrm{H}_{2} \mathrm{O}_{2}$ for 30 minutes at $25^{\circ} \mathrm{C}$ until bleached. They were rinsed thoroughly with water to remove the $\mathrm{H}_{2} \mathrm{O}_{2}$, acidified in dilute HCL and stained as described earlier. In some cases the modified method of Merryweather and Fitter (1991) was followed where autoclaving and bleaching with $\mathrm{H}_{2} \mathrm{O}_{2}$ were omitted. In a few cases, direct observation of unstained, fresh and intact roots (Arias et al., 1987) was made.

Arbuscular mycorrhizal infection in the roots was assessed following the grid line-intersect method of Giovannetti and Mosse (1980). The stained root pieces were spread out evenly on a square plastic Petri dish $(10.2 \times 10.0 \mathrm{~cm})$. A grid of lines was marked on the bottom of the dish to form $1 \mathrm{~cm}$ inch squares. Vertical and horizontal gridlines were scanned under a dissecting microscope and the presence of infection was recorded at each point where the roots intersected a line. Four sets of observations were made, recording 100, 200, 300 and all the root gridline intersects. Each of the three replicate records was made on a fresh re-arrangement of the same root sample.

The percentage of AM infection was calculated using the formula:

$\%$ of infection $=\frac{\text { No. of root segments infected }}{\text { Total no. of root segments }} \times 100$

When sufficient root pieces are not available, the slide method Giovannetti and Mosse (1980) was followed. Root pieces, $1 \mathrm{~cm}$ long, were selected at random from a stained sample and mounted on microscope slide groups of 10 . Presence of infection was recorded in each of the 10 pieces and percent infection was calculated. To observe hyphae, vesicles and arbuscules under light microscope, the root 
pieces were mounted on glass slides either temporarily in lacto phenol or permanently in polyvinyl alcohol resin-lacto phenol. The cover slip was pressed gently to make the roots flattened and sealed with DPX medium.

Isolation of Arbuscular mycorrhizal spores from soil samples:

Spores were recovered from soil samples by the wetsieving and decanting method (Gerdemann and Nicolson, 1963). From each soil sample, $100 \mathrm{~g}$ soil was taken and mixed with 1:1 of lukewarm water in a large beaker until all the aggregates dispersed to leave a uniform suspension. Heavier particles were allowed to settle down. To remove organic matter and roots, the suspension was decanted through a $710 \mu \mathrm{m}$ sieve. The suspension that passed through $710 \mu \mathrm{m}$ was decanted through $425 \mu \mathrm{m}, 250 \mu \mathrm{m}$, $150 \mu \mathrm{m}, 75 \mu \mathrm{m}$ and $45 \mu \mathrm{m}$ sieves consecutively. The residues in the respective sieve were collected in Petri dishes with about $10-20 \mathrm{ml}$ water observed under a dissecting microscope for AM fungal spores.

Total spore count was calculated by counting the spores. Then the spores were separated using a glass pipette and segregated. The spores were mounted on clear glass slides using lacto phenol or polyvinyl alcohol lacto phenol (PVL), covered with cover slips and sealed with DPX medium.

\section{Identification of AM fungi:}

Based up on microscopic characters, the AM spores were identified. For identification and nomenclature, synoptic keys of the following authors were used: Raman and Mohankumar (1988); Schenck and Perez (1990). Classification was based on colour, size, shape, surface, structure, general nature of the spore contents and hyphal attachment. Photomicrographs were taken with the help of a Magnus Olympic Microscope.

\section{Results}

Arbuscular mycorrhizal infection and spore population of 40 medicinal plant species belongs to 20 families present in the year 2009-2010 (Table: 1). Totally 40 plant species including shrubs, herbs belong to 20 families were examined for arbuscular mycorrhizal fungal association. Of these, maximum spore population displayed in the plant species of Lencas aspera (690/100g soil) belongs to the family Lamiaceae and minimum spore population was recorded in the plant species of Spilanthes radicans (170/100g soil) belongs to the family Asteraceae.

The highest AM fungal infection found in the roots of Centella asiatica $(80 \%)$ belongs to the family of
Apiaceae. The lowest fungal infection was found to the Triumfetta rhomboidea (30\%) of Tiliaceae member.

The plant species Urena lobata (38\%), Triumfetta rhomboidea (30\%), Osbeckia octandra (32\%), Spermacoce ocymoides (39\%), Elephantopus scaber (40\%), Spilanthes radicans (36\%), Spilanthes ciliata (38\%), Scoparia dulcis (38\%), and Elatostema lineolatum (33\%) showed 40\% and less than $40 \%$ of infection.

The plant species Sida rhombifolia (46\%), Mimosa pudica (43\%), Ludwigia octovalvis (43\%), Hydrocotyle javanica (48\%), Vernonia cinerea (42\%), Pogostemon paniculatus (50\%) and Asparagus racemosus (45\%) showed $50 \%$ and less than $50 \%$ of infection.

The plant species Blumea membranaceae (59\%), Solanum nigrum (57\%), Lindernia antipoda (56\%), Strobilanthes heyneanus (58\%) and Panicum brevifolium (60\%) showed $60 \%$ and less than $60 \%$ infection.

The plant species Erechtites valerianifolia (62\%), Rauvolfia serpentine (63\%), Solanum surattenses (65\%), Ageratum conyzoides (70\%), Mecardonia procumbens $(70 \%)$, Lantana camara $(70 \%)$ and Sarcandra chloranthoides $(70 \%)$ showed $70 \%$ and less than $70 \%$ of infection.

The medicinal plant species Centella asiatica (80\%), Dichrocephala integrifolia (75\%), Wedelia trilobata (73\%), Rauvolfia verticillata $(73 \%)$, Solanum torvum (74\%), Andrographis macrobotrys (71\%), Stachytarpheta jamaicensis (76\%), Leucas aspera (78\%), Polygonum chinense (78\%), Kyllinga monocephala (73\%), Ophiorrbiza mungos (76\%) and Paspalum conjugatum (75\%) showed $80 \%$ and less than $80 \%$ of infection.

Totally 36 arbuscular mycorrhizal fungal species were recovered from the rhizosphere of 40 medicinal plant species belongs to 20 plant families (Fig.1). Except for the genus Entrophosphora rest of the five genera of AM fungi were encountered during the present study. Of these one species from Acaulospora (Aca. rehmii), two species from Gigaspora (Gig. rosea and Gig. albida), 27 species from Glomus, Gl. albidum, Gl. ambisporum, Gl. arborense, Gl. australe, Gl. boreale, Gl. botryoides, Gl. canadense, Gl. citricola, Gl. claroides, Gl. constrictum, Gl. delbiense, Gl. fecundisporum, Gl. fistulosum, Gl. flavisporum, Gl. fulvum, Gl. hoi, Gl. intraradices, Gl. invermayanum, Gl. macrocarpum, Gl. maculosum, Gl. magnicaule, Gl. multicaule, Gl. multisubtensum, Gl. radiatum, Gl. tenebrosum, Gl. tortuosum, Gl. vesiculiferum, and one species from Sclerocystis (Sclerocystis rubiformis) and 6 species from Scutellospora, Scu. auriglobosa, Scu. beterogama, Scu. nigra, Scu. reticulata and Scu. scutata. The genus Glomus was recorded more frequently. The arbuscular mycorrhizal spores Gl. fasciculatum was found dominant followed by Gl. intraradices. 

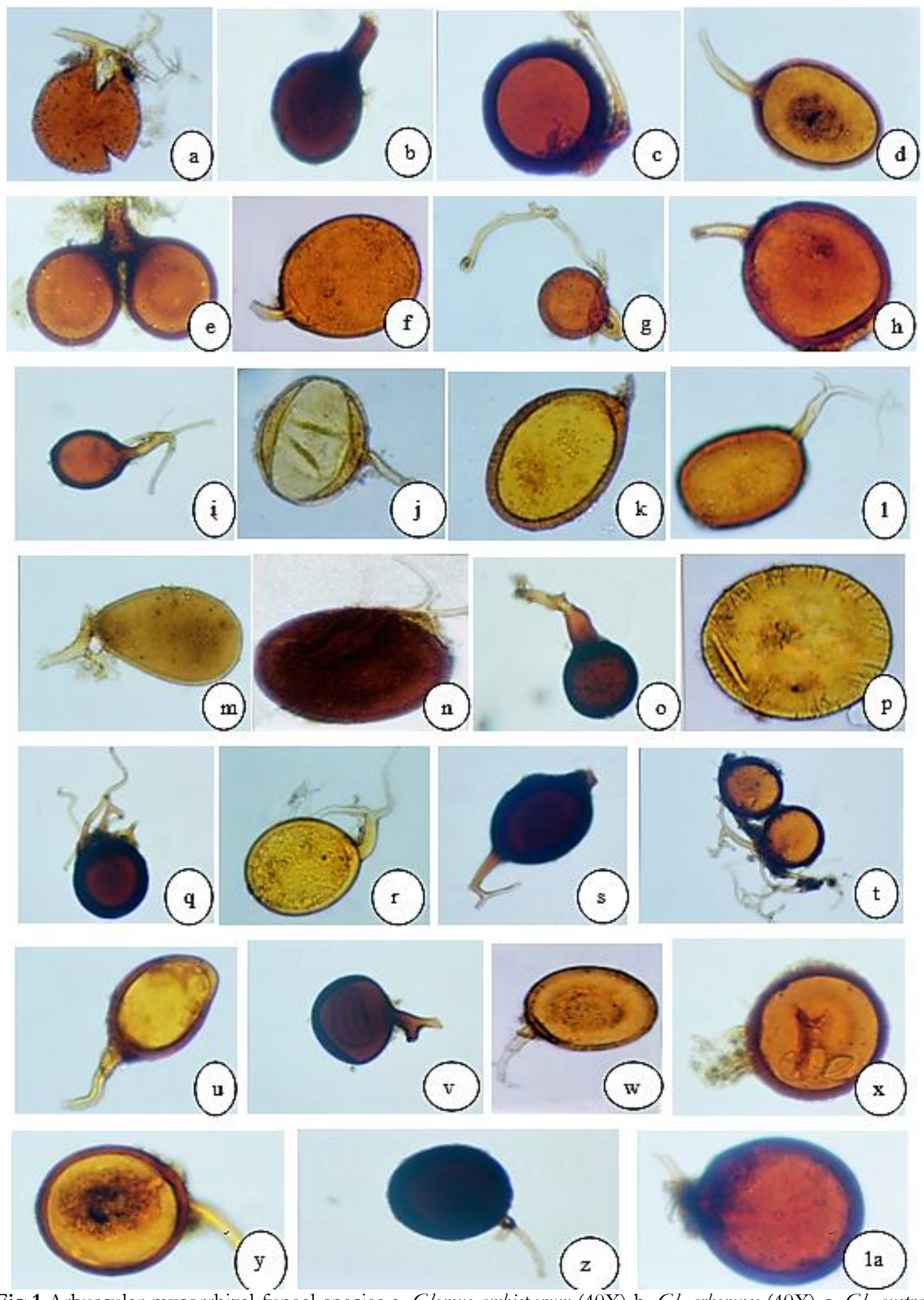

Fig.1 Arbuscular mycorrhizal fungal species a. Glomus ambisporum (40X) b. Gl. arborense (40X) c. Gl. australe $(40 \mathrm{X})$ d. Gl. boreale $(40 \mathrm{X})$ e. Gl. botriyoides $(40 \mathrm{X})$ f. Gl. canadense $(40 \mathrm{X})$ g. Gl. citricola $(20 \mathrm{X})$ h. Gl. claroides $(120 \mathrm{X})$ i. Gl. fasciculatum (40X) j. Gl. fecundisporum (120X) k. Gl. fistulosum (120X) 1. Gl. flavisporum (120X) m. Gl. fulvum (120X) n. Gl. intraradices (120X) o. Gl. invermayanum (20X) p. Gl. macrocarpum (120X) q. Gl. maculosum (40X) r. Gl. magnicaule $(120 \mathrm{X})$ s. Gl. multicaule $(40 \mathrm{X})$ t. Gl. multisubtensum $(20 \mathrm{X})$ u. Gl. radiatum $(40 \mathrm{X})$ v. Gl. tenebrosum $(120 X)$ w. Gl. vesiculiferum (180X) x. Scutellospora auriglobosa (180X) y. Scu. heterogama (180X) z. Scu. nigra (180X) 1a. Scu. scutata (180X). 
Table 1. AM fungal infection and spore population of medicinal plant species collected in and around the areas of Pookode Lake

\begin{tabular}{|c|c|c|c|c|c|c|c|c|}
\hline \multirow{2}{*}{$\begin{array}{l}\text { S. } \\
\text { No. }\end{array}$} & \multirow{2}{*}{$\begin{array}{l}\text { Name of the } \\
\text { plant species }\end{array}$} & \multirow[t]{2}{*}{ Habit } & \multicolumn{3}{|c|}{ Type of Infection } & \multirow{2}{*}{$\begin{array}{c}\% \text { of } \\
\text { Infection }\end{array}$} & \multirow{2}{*}{$\begin{array}{c}\text { Spore } \\
\text { Population } \\
\text { per } 100 \mathrm{gm} \\
\text { soil } \\
\end{array}$} & \multirow[t]{2}{*}{ AM Fungal spores } \\
\hline & & & Hyphae & Vesicles & Arbuscules & & & \\
\hline \multicolumn{9}{|c|}{ MALVACEAE } \\
\hline 1. & $\begin{array}{l}\text { Sida rhombifolia } \\
\text { Linn. }\end{array}$ & $\begin{array}{l}\text { Under } \\
\text { shrub }\end{array}$ & + & - & + & $46 \%$ & 487 & $\begin{array}{l}\text { Gigaspora rosea } \\
\text { Glomus boreale } \\
\text { Gl. citricola } \\
\text { Gl. fistulosum } \\
\text { Gl. fasciculatum }\end{array}$ \\
\hline 2 & $\begin{array}{l}\text { Urena lobata } \\
\text { Linn. }\end{array}$ & Shrub & + & - & + & $38 \%$ & 285 & $\begin{array}{l}\text { Acaulospora rehmii } \\
\text { Glomus canadense } \\
\text { Gl. hoi } \\
\text { Gl. intraradices } \\
\text { Scutellospora nigra }\end{array}$ \\
\hline \multicolumn{9}{|c|}{ TILIACEAE } \\
\hline 3 & $\begin{array}{l}\text { Triumfetta } \\
\text { rhomboidea, } \\
\text { Jacq. }\end{array}$ & Herb & + & - & + & $30 \%$ & 300 & $\begin{array}{l}\text { Acaulospora rehmii } \\
\text { Gigaspora albida } \\
\text { Glomus ambisporum } \\
\text { Gl. invermayanum } \\
\text { Scutellospora scutata }\end{array}$ \\
\hline \multicolumn{9}{|c|}{ MIMOSACEAE } \\
\hline 4 & $\begin{array}{l}\text { Mimosa pudica } \\
\text { L. }\end{array}$ & Herb & + & + & + & $43 \%$ & 525 & $\begin{array}{l}\text { Glomus delbiense } \\
\text { Gl. flavisporum } \\
\text { Gl. radiatum } \\
\text { Gl. fasciculatum } \\
\text { Scutellospora } \\
\text { beterogama } \\
\text { Scu. nigra }\end{array}$ \\
\hline \multicolumn{9}{|c|}{ MELASTOMACEAE } \\
\hline 5 & $\begin{array}{l}\text { Osbeckia } \\
\text { octandra DC. }\end{array}$ & Shrub & + & + & - & $32 \%$ & 225 & $\begin{array}{l}\text { Acaulospora rehmii } \\
\text { Gigaspora rosea } \\
\text { Glomus constrictum } \\
\text { Gl. intraradices }\end{array}$ \\
\hline \multicolumn{9}{|c|}{ ONAGRACEAE } \\
\hline 6 & $\begin{array}{l}\text { Ludwigia } \\
\text { octovalvis (Jacq.) } \\
\text { Raven. }\end{array}$ & Herb & + & + & - & $43 \%$ & 375 & $\begin{array}{l}\text { Glomus arborense } \\
\text { Gl. fulvum } \\
\text { Gl. fasciculatum } \\
\text { Gl. tortuosum } \\
\text { Sclerocystis rubiformis } \\
\text { Scutellospora nigra }\end{array}$ \\
\hline \multicolumn{9}{|c|}{ APIACEAE } \\
\hline 7 & $\begin{array}{l}\text { Centella asiatica } \\
\text { (L.) Urban. }\end{array}$ & Herb & + & - & + & $80 \%$ & 560 & $\begin{array}{l}\text { Acaulospora rehmï } \\
\text { Gigaspora albida } \\
\text { Glomus australe } \\
\text { Gl. fasciculatum } \\
\text { Gl. fecundisporum } \\
\text { Scutellospora nigra }\end{array}$ \\
\hline 8 & $\begin{array}{l}\text { Hydrocotyle } \\
\text { javanica Thunb. }\end{array}$ & Herb & + & + & - & $48 \%$ & 300 & $\begin{array}{l}\text { Gigaspora rosea } \\
\text { Glomus fasciculatum } \\
\text { Gl. magnicaule } \\
\text { Gl. tenebrosum }\end{array}$ \\
\hline \multicolumn{9}{|c|}{ RUBIACEAE } \\
\hline 9 & $\begin{array}{l}\text { Ophiorrbiza } \\
\text { mungos Linn }\end{array}$ & $\begin{array}{l}\text { Under } \\
\text { shrub }\end{array}$ & + & + & - & $76 \%$ & 645 & $\begin{array}{l}\text { Glomus claroides } \\
\text { Gl. fasciculatum } \\
\text { Gl. intraradices } \\
\text { Gl. macrocarpum } \\
\text { Gl. vesiculiferum }\end{array}$ \\
\hline 10 & $\begin{array}{l}\text { Spermacoce } \\
\text { ocymoides Burm. } \\
\text { f. }\end{array}$ & Herb & + & + & - & $39 \%$ & 337 & $\begin{array}{l}\text { Gigaspora albida } \\
\text { Glomus multicaule } \\
\text { Scutellospora } \\
\text { auriglobosum }\end{array}$ \\
\hline \multicolumn{9}{|c|}{ ASTERACEAE } \\
\hline 11 & $\begin{array}{l}\text { Ageratum } \\
\text { conyzoides Linn. }\end{array}$ & Herb & + & + & - & $70 \%$ & 525 & $\begin{array}{l}\text { Glomus albidum } \\
\text { Gl. boi } \\
\text { Gl. tortuosum } \\
\text { Sclerocystis rubiformis }\end{array}$ \\
\hline 12 & $\begin{array}{l}\text { Blumea } \\
\text { membranacea } \\
\text { (DC.) Hook. f. }\end{array}$ & Herb & + & + & - & $59 \%$ & 562 & $\begin{array}{l}\text { Glomus arborense } \\
\text { Gl. canadense } \\
\text { Gl. fulvum } \\
\text { Gl. intraradices }\end{array}$ \\
\hline 13 & $\begin{array}{l}\text { Dichrocephala } \\
\text { integrifolia (L.F.) } \\
\text { O. Kuntze. }\end{array}$ & Herb & + & + & - & $75 \%$ & 568 & $\begin{array}{l}\text { Acaulospora rehmii } \\
\text { Glomus citricola } \\
\text { Gl. radiatum }\end{array}$ \\
\hline
\end{tabular}




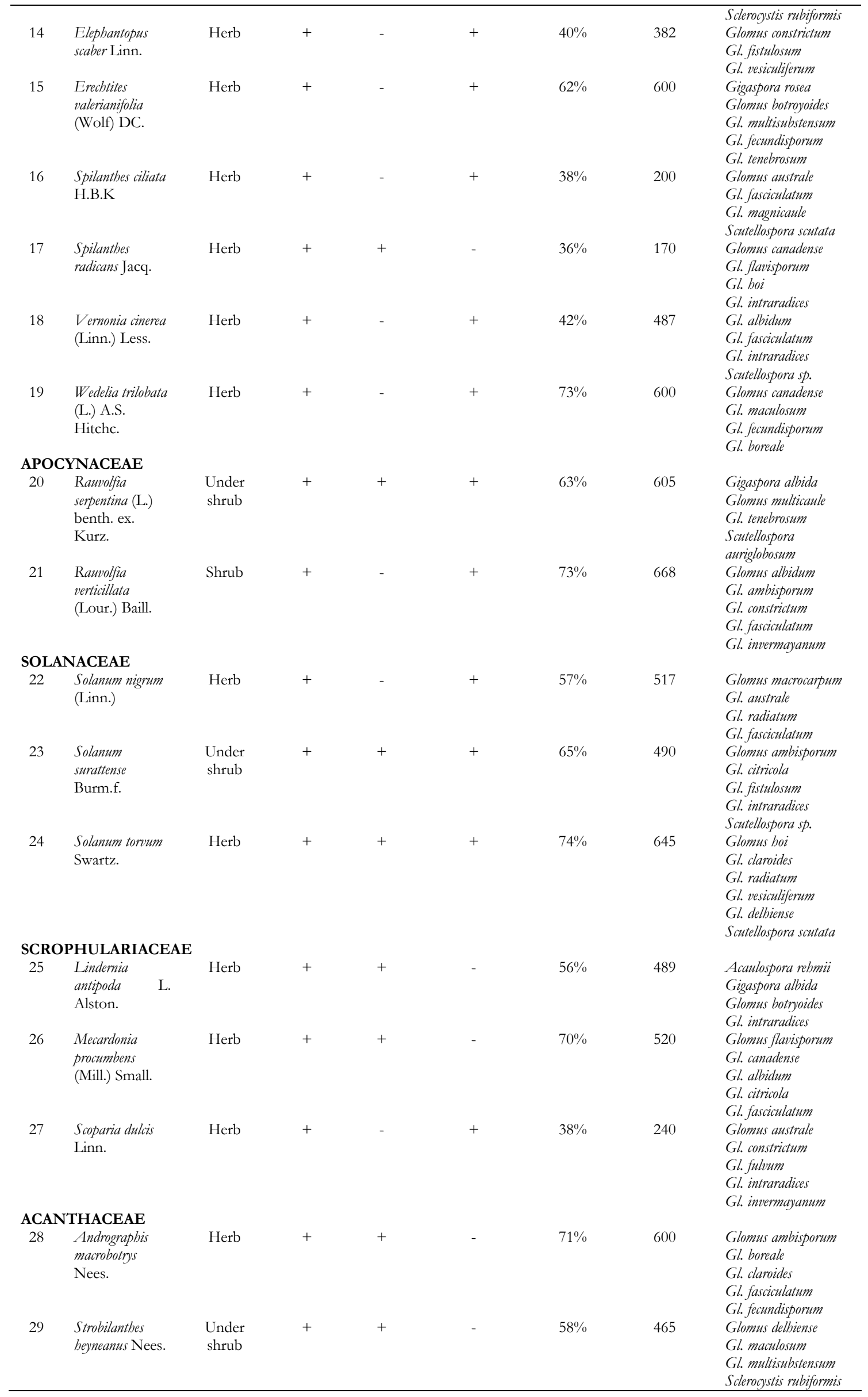




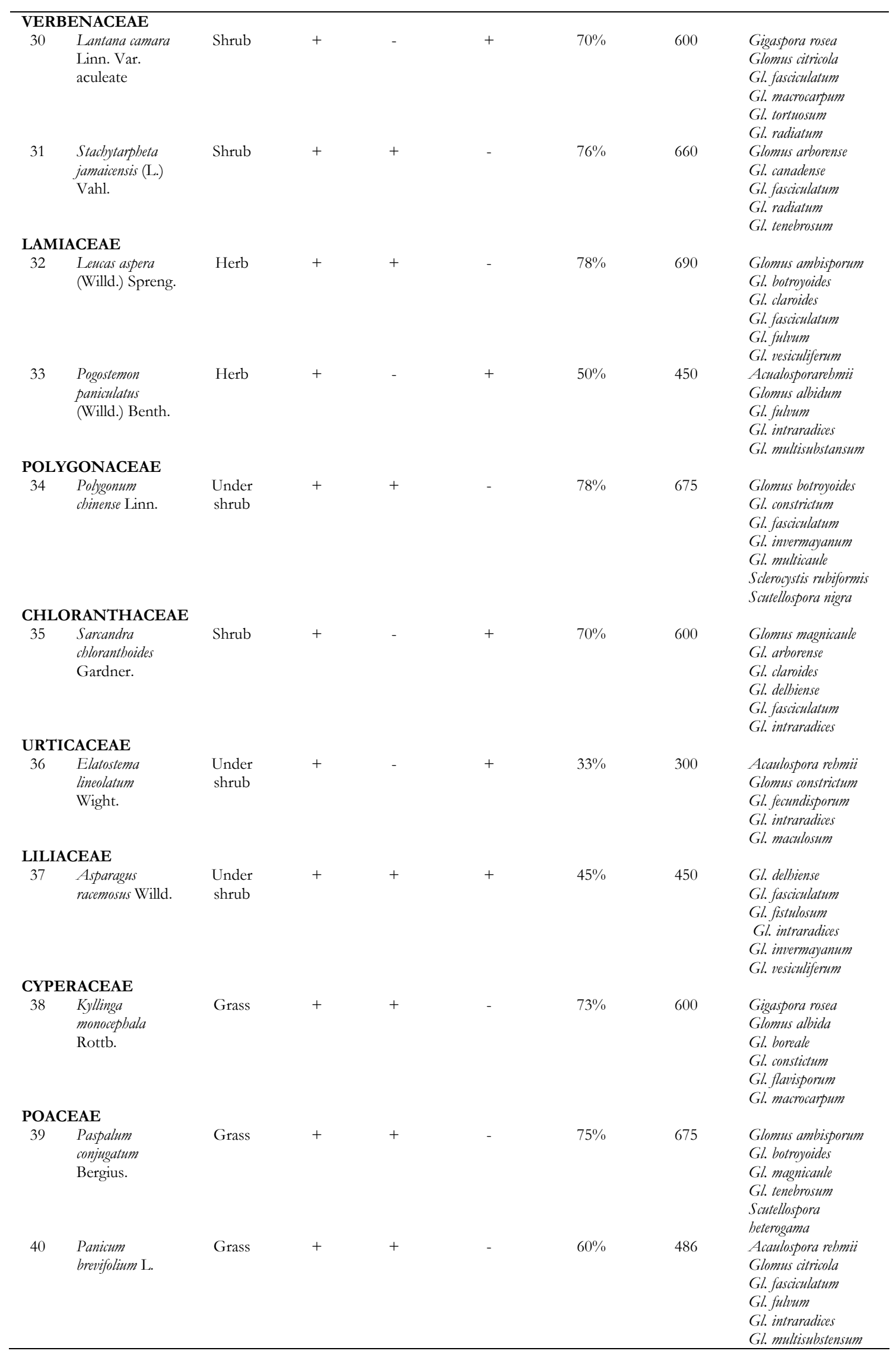




\section{Discussion}

In Kerala the Pookode lake area plant species were analyzed to determine for mycorrhizal infection and spore population for a period of one year. All the plant species showed mycorrhizal association. Totally 40 plant species belongs to 20 families were surveyed for AM fungal association. The root colonization ranged from $30 \%$ to $80 \%$ and the AM fungal spore density ranged from 170 to 690 per 100 gm of soil.

The populations of spores as well as the percentage of infection of all the samples were varied in all the plant species of Pookode area. Edaphic factors also play an important role in spore germination and colonization, along with plant factors like age, lifespan and root density (Abbott and Robson, 1991). Formations of AM fungal structures were inconsistent and fluctuating from site to site. Colonization and sporulation by AM fungi are influenced by a wide range of environmental, plants and fungal factors (Khalil et al., 1992).

Mohankumar and Mahadeven (1986) find out no mycorrhizal association in the families of Acanthaceae and Verbenaceae in mangrove vegetation. Muthukumar et al., (1994) observed the AM fungal colonization in Mimosa pudica $(74.45 \%)$ belongs to the family Mimosaceae. Similarly, the same result was obtained in the present investigation and the plant species Mimosa pudica showed only $43 \%$ of AM fungal infection.

The present study reveals that there was no consistent relationship between organic matter, $\mathrm{pH}$ of the soil that of the number of spores in soils. Similar findings were reported by early workers (Warner \& Mosse, 1980, Mohankumar and Mahadevan, 1988). Prasad (2005) displayed the AM infection and find out the maximum in Cyperus rotundus (40\%), Cyperaceae followed by Cynodon dactylon (36\%) (Graminae) and Solanum sp (Solanaceae) from Bettiah, Bihar. The AM fungal infection was observed $73 \%, 75 \%$ and $74 \%$ in the other species of families Cyperaceae, (Kyllinga monocephala), Graminae (Paspalum conjugatum), and Solanaceae (Solanum torvum) respectively.

The present study brought out that most of tree species were colonized by AM. Almost all forest trees recorded AM colonization in the roots besides the presence of their spores in the rhizosphere. Ragupathy et al., 1988 reported the absence of mycorrhizal infection in Colocasia esculenta (Araceae) and Borreria hispida belongs to the family Rubiaceae. But in contrast the present study reveals that the Rubiaceaea members Ophiorrbiza mungos and Spermacoce ocymoides infected $76 \%$ and $39 \%$ respectively.
Among the members of Astreraceae the species richness and diversity of AM fungi and infection has highest in Dichrocephala integrifolia (75\%) followed by Ageratum conyzoides (70\%). The same result was obtained in the species Ageratum conyzoides (70\%) belongs to the family (Asteraceae) from coastal sand dunes of West coast of India (Beena et al., 2001). Their studies also indicates that the Lamiaceae member Leucas aspera infected (75\%) by AM fungal infection (Beena et al., 2001). Kumar et al. (2003) also reported the AM fungal colonization $(50 \%)$ in roots of the plant species Ageratum conyzoides.

The present study confirms the presence of AM colonization in medicinal plants. Similar observations were recorded earlier (Taber and Trappe, 1982; Muthukumar et al., 2001; Sadiq Gorsi, 2002). The mycorrhizal colonization differed among medicinal plant species and there was a considerable variation in percent root colonization and number of different arbuscular mycorrhizal fungal spores associated with rhizosphere soil samples of plant species.

Thirty-six AM fungal species belonging to five genera were recovered from the rhizosphere soil in the present study. This is in agreement with the findings of Francis and Read (1994) and Allen et al, (1995) who reported high AM fungal species diversity in medicinal plants. The medicinal plant species Asparagus racemosus and Solanum nigrum (Solanaceaea) was infected by AM fungal infection 40 \& 30\% respectively from Azad Jammu and Kashmir (Sadiq Gorsi, 2002). The present study reveals the similar results that the Asparagus racemosus (Liliaceaea) 45\% and Solanum nigrum (Solanaceae) $57 \%$ infected by AM fungi. Kumar (2008) reported AM fungal association in Sida cordifolia (Meliaceae) from different parts of Karnataka which is in consistence with this present study.

Many common wetland plant families, most notably the cyperaceae had been previously as nonmycorrhizal because in few species roots observed to harbor the fungus (Powell, 1975; Newman and Reddell, 1987; Brundrett, 1991; Smith and Read, 1997) but there have been numerous reports of mycorrhizal colonization in certain Cyperaceae species (Wetzel and Van der Valk, 1996). The present study also confirmed that one of the Cyperaceae member Kyllinga monocephala (73\%) was infected by AM fungi.

\section{References}

1. Abbott L. K and A. D. Robson. "Factors influencing the occurrence of vesiculararbuscular mycorrhiza." Agriculture, Ecosystems and Environmen, 35.2-3 (1991): 121-150. Print.

2. Allen E. B, M. F. Allen, D. J. Helm, J. M. Trappe, R. Moliva, and E. Rincon. "Patterens 
and regulation of mycorrhizal and fungal diversity." Plant and Soil 170.1 (1995): 47-62. Print.

3. Arias I, M. J. Sainz, C. A. Grace, and D. S. Hayman. "Direct observation of vesicular arbuscular mycorrhizal infection in fresh unstained roots." Transactions of the British Mycological Society 89.1 (1987): 128-131. Print.

4. Beena K. R, A. B. Arun, N. S. Raviraja, and K. R. Sridhar. "Association of arbuscular mycorrhizal fungi with plants of coastal sand dunes of west coast India." Tropical Ecology 42.2 (2001): 213-222. Print

5. Brachmann A and M. Parniske. "The most widespread symbiosis on earth." PLoSBiol 4.7 (2006): e239.

6. Brundrett M. "Mycorrhizas in natural ecosystem." In: MacfaydenBegon M and Fitter $\mathrm{AH}$ (eds). Advances in Ecological Research, Academic Press London, 21(1991): 171-173.

7. Cade-menun B. J, S. M. Berch, and A. A. Bomke. "Seasonal colonization of winter wheat in south coastal British Columbia by vesicular arbuscular mycorrhizal fungi." Can J Bot 69.1 (1991): 78-86. Print.

8. Cairney, J. W. G. "Evolution of mycorrhiza systems." Naturwissenschaften 87.11 (2000): 467475.

9. Kumar K. V. C, K. R. Chandrashekar, and R. Lakshmipathy. "Variation in arbuscular mycorrhizal fungi and phosphatase activity associated with Sida cordifolia in Karnataka." World Journal of Agricultural sciences 4.6 (2008): 770-774. Print.

10. Francis R. and D. J. Read. "The contributions of mycorrhizal fungi to the determination of plant community structure." Plant and Soil 159.1 (1994): 11-25. Print.

11. Gerdemann J. W. and T. H. Nicolson. "Spores of mycorrhizal Endogone species extracted from soil by wet sieving and decanting." Trans Br MycolSc 46.2 (1963): 235-244. Print.

12. Giovanneti M. and B. Mosse. "An evaluation of techniques for measuring vesicular arbuscular mycorrhizal infection in roots." New Phytol 84 (1980): 489-500.

13. Harley J. L. "The significance of mycorrhiza." Mycol. Res 92.2 (1989): 129-139.

14. Prasad K. "Arbuscular mycorrhizal fungal occurrence in non-cultivated disturbed and non- fertile land of Bettiahraj, Bettiah, Bihar." Mycorrbiza News 16 (2005): 12.

15. Khalil S, T. E. Loynachan, and H. S. McNabb. "Colonization of soybean by mycorrhizal fungi and spore populations in Iowa soils." Agro J 84.5 (1992): 832-836.

16. Kumar A, R. Raghuwanshi, and R. S. Upadhyay. "Vesicular-arbuscular mycorrhizal association in naturally revegetated coal mine spoil." Tropical Ecology 44.2 (2003): 251-254.

17. Mathew K M. "The flora of the Tamilnadu Carnatic." Gamopetalae and Monochlamydeae, The Rapinat Herbarium, St.Joseph's College, Tiruchirapalli, 1983, 2154p.

18. Merryweather J. W. and J. H. Fitter. "A modified method for elucidating the structure of the fungal partner in vesicular-arbuscular mycorrhizae." Mycol Res 95.12 (1991): 14351437. Print.

19. Mohankumar V. and A. Mahadevan. "VA mycorrhizal distribution with respect to organic matter content of soil in a tropical forest." Trop Ecol 29.1 (1988): 55-62.

20. Muthukumar T, K. Udaiyan, and S. Manian. "Vesicular-arbuscular mycorrhizae in certain tropical wild legumes." Ann Forestr 2 (1994): 3343.

21. Muthukumar T, K. Udaiyan, and S. Manian. "Vesicular-arbuscular mycorrhizal association in the medicinal plants of Maruthamalai Hills, Western Ghats, Southern India." Journal of Mycology and Plant Pathology 31.2 (2001): 180-184. Print.

22. Newman E. I. and P. Reddell. "The distribution of mycorrhizas among families of vascular plants." New Phytologist 106.4 (1987): 745-751.

23. O’Neill E. G, R. V. O’Neill, and R. J. Norby. "Hierarchy theory as a guide to mycorrhizal research on large-scale problems." Environ Poll 73.3-4 (1991): 271-284.

24. Peterson R. L, A. E. Ashford, and W. G. Allaway. "Vesicular-arbuscular mycorrhizal association of vascular plants on Heron Island, a Great Barrier Reef Coral cay." Australian Journal of Botany 33.6 (1985): 669-676.

25. Phillips J. M. and D. S. Hayman. "Improved procedures for clearing roots and staining parasitic and vesicular-arbuscular mycorrhizal fungus for rapid assessment of infection." Trans Br MycolSc 55.1 (1970): 158-161. 
26. Powell C. L. "Field inoculation with VA mycorrhizal fungi." Pages 205-222 in: VA Mycorrbizae, Powell C. L. and D. J. Bagyaraj, eds. CRC Press, Inc., Boca Raton, FL, 1984.

27. Powell C. L. "Rushes and sedges are nonmycotropic." Plant Soil 42.2 (1975): 481-484.

28. Ragupatty S, V. Mohankumar, and A. Mahadevan. Distribution of VAM in Thanjavur district flora, In Proceedings: Mycorrhizae for Green Asia, First Asian Conference on Mycorrhizae (eds. Mahadevan A. N, Rahman, and K. Natarajan), CAS in Botany University of Madras, 1988, 95-98.

29. Raman N, and V. Mohankumar. Techniques in mycorrhizal research, University of Madras, Madras, 1988, 279.

30. Sadiq Gorsi M. "Studies on Mycorrhizal Association in some Medicinal Plants of Azad Jammu and Kashmir." Asian Journal of Plant Sciences 1.4 (2002): 383-387.

31. Schenck N. C. and Y. Perez. "Manual for the identification of VA Mycorrhizal fungi"
INVAM. Gainesville, Synergistic Publications, 286 (1990).

32. Smith S. E. and D. J. Read. "Mycorrhizal symbiosis." Academic Press, Inc San Diego California, 1997, ISBN 0-12-652840-3.

33. Taber R A and J. M. Trappe. "Vesicular arbuscular mycorrhizae in rhizomes, scale likeleaves, root and xylem of ginger." Mycologia 74.1 (1982): 156-161.

34. Warner A. and B. Mosse. "Independent spread of VA mycorrhizal fungi in soil." Trans Brit MycolSco 74 (1980): 407- 410.

35. Wetzel P. R. and A. G. V. D. Van. "Vesiculararbuscular mycorrhizae in prairie pothole wetland vegetation in Iowa and North Dakota." Can J Bot 74.6 (1996): 883-890.

\section{Cite this article as:}

Saranya Babu Jayaprakash C. M. and N. Nagarajan. Studies on mycorrhizal biodiversity in medicinal plant species of Pookode Lake area, Wayanad, India. Annals of Plant Sciences 6.12 (2017) pp. 1835 1844.

doi: http://dx.doi.org/10.21746/aps.2017.6.12.6 